\title{
Creating capabilities in local environments and production networks
}

\section{Gabriel Yoguel}

Research Fellow,

Instituto de Industria Nacional, Universidad Nacional

de General Sarmiento,

Argentina

yoguel@mail.retina.ar
In the new international setting, which is characterized by new technologies that make intensive use of information, globalization of markets, and the increased competitive pressures and uncertainty facing the agents, competitiveness is a systemic phenomenon. The endogenous capabilities of the agents, the degree of development of the environment they operate in and their integration in a production network have become key elements for developing capabilities and creating competitive advantages. It is being asserted more and more frequently that the competitive advantages of countries, regions and agents do not necessarily derive from their factor endowments but can be constructed through the development of endogenous capabilities and linkages with other agents. In the transition from static to dynamic advantages, the capacity to learn-conceived as an interactive process imbuing the whole of society- plays a key role. The present article analyses what the endogenous mechanisms for the creation of capabilities and the conversion of generic knowledge into specific know-how are, and what they depend on, at the level of the individual agents, production networks and the various local environments. Reference is made to the importance attached by economic theory in recent years to the relation between technology and learning processes, especially in the Schumpeterian and evolutionary approaches. The way in which the economic agents learn, transform generic knowledge into specific know-how and link up codified and tacit forms of knowledge is addressed, and finally it is emphasized that these processes are not the result of the natural linear development of production systems but are the consequence of a long evolutionary learning process. 


\section{I}

\section{Introduction}

Important changes have taken place in the international setting over the last twenty years, especially the globalization of markets, the generalized spread of economic openness processes and the appearance of new technical and organizational models which involve intensive use of information. These changes have brought into question the idea of competitiveness as a purely macroeconomic and sectoral phenomenon, determined by static comparative advantages or by the resource endowment.

The volatility of demand, the segmentation of markets, the shortening of product life cycles, the strategic uncertainties associated with the new world situation and the possibility of combining economies of scale and of variety have meant a considerable increase in the competitive pressures that the economic agents must face. In addition to the traditional macroeconomic and sectoral factors which previously formed the key elements of competitiveness, there are now other elements which depend on the agents' conduct and on the nature of the economic and social environment in which they operate. As a result, competitiveness is now seen as a systemic phenomenon and both the agents' conduct and the degree of development of the local environment have taken on great importance in the creation of competitive advantages. The conviction is therefore growing up that the competitive advantages of countries, regions and agents do not necessarily depend on their factor endowment.

The new concepts are based on the idea that comparative advantages can be created and are therefore dynamic. In the transition from static comparative advantages to dynamic advantages, a key role is played by technology and by learning processes. The capacity to learn -conceived as an interactive process incorporated within the very fabric of society- and the development of "agent capabilities" will determine the economic success of firms, regions and countries (Ernst and Lundvall,

\footnotetext{
$\square$ An earlier version of this study was presented at the Seminar on Local Innovation Systems held in Rio de Janeiro on 14-15 December 1998. The author wishes to express his gratitude for the comments on previous versions of this article made by his colleagues at the Instituto de Indústria and by Graciela Gutman and Bernardo Kosacoff, as well as the observations of one of the anonymous referees who collaborate with CEPAL Review.
}

1997). Consequently, in this new context a factor of the greatest importance for the creation of comparative advantages is the reactions of enterprises aimed at conceiving, planning and implementing the development and improvement of products and processes, at introducing organizational changes, and at establishing new forms of linkages with the market. In other words, in the process of competition and the search for differentiation the agents seek to improve their technological capabilities (Lall, 1992), understood as their potential to turn generic knowledge into specific know-how through static and dynamic capabilities derived from formal and informal learning (Boscherini and Yoguel, 1996a). Static capabilities may be defined as the set of formal and informal technological and organizational knowledge and skills that the agents generate in order to carry out their projects. They are not confined to information and equipment, but also include organizational capacity, patterns of conduct and routines affecting the decisionmaking process.

The present article aims to review the latest advances in this field described in the most recent literature, in order to understand what the endogenous mechanisms for the creation of capabilities and the conversion of generic knowledge into specific know-how are, and what they depend on, at the level of the individual agents, production networks and the various local environments. It is of the greatest interest to find out how the economic agents learn and how they turn generic knowledge into specific know-how: in short, how they innovate.

The studies analysed for this purpose were carried out in the developed countries and deal in particular with the new importance of learning processes in the creation of competitive advantages in industrial districts, industry clusters, and what is called the new territorial capability (Poma (forthcoming)). However, this analysis is also relevant to Latin America too. Even though in the 1990s the tendencies towards growing primary-sector domination of the production structure and the trade specialization profile became still more pronounced (ECLAC, 1996), it is obvious that reduction of the productivity differences with respect to the most highly developed countries, the sustainability over time of the models being applied, and the reduction of inequalities in income distribution will call for a higher level of complexity and 
the incorporation of a higher proportion of both codified and tacit knowledge in the agents' production functions. It may be noted that in some agro-industries which have made notable advances in this new system of industrial specialization, in recent years the production processes have attained increasingly high levels of complexity, reflected in the growing importance of information-intensive technologies (Gutman, 1999).
In section II of this article, an analysis will be made of the role of learning processes in economic theory, with special emphasis on the new theoretical approaches. Section III looks at the role of tacit knowledge and the development of competitive advantages in the technical and labour-related capabilities of the agents, and section IV analyses learning processes in local systems and in industry clusters. Finally, section V presents some conclusions.

\section{II}

\section{Technology, the firm, and the generation of knowledge: the latest theoretical approaches}

Over the last fifteen years, the linkages between technology and learning processes have attracted renewed attention in economic theory, and this subject is constantly evolving. In this context, there is only a feeble relation between the theoretical framework of the technology commonly used and the appearance of these new processes in society. For example, neoclassical economic theory is based on a conception of the enterprise in which the economic agents always seek to maximize their performance, operate in conditions of perfect rationality and access to information, and are working in an environment where there is no uncertainty and there are rational expectations. In this context, capital is assumed to be malleable -the "jelly mould" theory- and technology is seen as a set of production techniques - a library containing all possible information and readily accessible to all the agents- which can be chosen and applied without difficulty at zero cost in terms of the relation between profit rates and wage rates (Solow, 1963). In order to select the best techniques, the agents weigh the latest advances in this set of techniques against the prevailing wage/profits ratio. When the wage/profits ratios go down from high levels to lower ones, the agents change labour-intensive techniques for others which are more capital-intensive. It is also assumed that the techniques are ordered in a manner functional to decreasing factor returns and that the price thresholds of the factors corresponding to each technique selected are crossed only once, in the direction corresponding to a production function with decreasing returns (Samuelson, 1962). Consequently, a labour-intensive technique with a high level of profitability cannot be used at a lower rate and the possibility of changing techniques is therefore ruled out.
The selection of techniques and their replacement when there are changes in the distribution conditions take place instantaneously and do not require a learning process.

In this standard neoclassical framework, which survived the old debate on the theory of capital in spite of the change of position by the participants, ${ }^{1}$ it is assumed that technical progress is not incorporated into the production function and is independent of capital accumulation. Consequently, the acquisition of knowledge and the learning process of the agents do not constitute an explanatory argument connected with the production function and are considered to be independent of the social capital of the agents. Although some models incorporate the existence of learning curves to which the shift in the production function is ascribed -non-incorporated technical progress- this learning is considered to be exogenous and independent of the factors of production (especially social capital) and therefore does not affect them.

\footnotetext{
${ }^{1}$ Samuelson (1962) admits that the simple accounts of Jevons, BohmBawerk, Wicksell and other neoclassical authors, according to which as the interest rate goes down as a result of abstention from present consumption in favour of future consumption, technology must in some way become more indirect, more mechanized and more productive, may not be universally valid. At the end of his work, he acknowledges that we owe a debt of gratitude to Pasinetti, Morishima, Garegnani and others for having shown that reversal is a logical possibility in any technology. In a noteworthy demonstration of intellectual honesty, Samuelson says that if all this causes dismay among those who yearn for the old parabolas of neoclassical theory, we should remember that academics were not born to enjoy an easy existence but must respect and give their due weight to the facts of life.
} 
The inability of this theory to be applied empirically to explain the changes occurring in the structure of production gave rise to other interpretations which -in the light of the new international trade theory and growth theory- led to changes in some of the assumptions of the standard neoclassical model. Thus, for, example, Grossman and Helpmann (1992) developed a growth theory which endogenizes technical progress in the production function and shows that the possibility of strategic interaction between agents, research and development activities, the existence of economies of scale and learning processes is of key importance for the creation of competitive advantages and for explaining the agents' pattern of specialization in foreign trade. On the basis of a general equilibrium scheme, they consider that the agents' decisions to invest in research and development ${ }^{2}$ and the benefits of the innovations arising from this depend on the conditions of operation of the market as a whole. Thus, the process of accumulation of knowledge endogenously generates the increases in productivity which sustain growth.

The most important change with regard to the explicit incorporation of knowledge into the theory, however, derives from the various neo-Schumpeterian and evolutionary schools of thought, which departed from the general equilibrium theory and implicitly accepted the existence of transactions effected under conditions of imbalance. ${ }^{3}$ To put it in a very stylized manner, these theories start from a different conception of the enterprise and technology and assign a key role to the learning processes, both formal and informal, that the agents

\footnotetext{
${ }^{2}$ In that theoretical framework, the knowledge generation process is limited to formal research and development laboratories.

${ }^{3}$ Although there is no desire here to place the work within any particular epistemological conception, it may be noted that the different elements in the body of neo-Schumpeterian theory -which breaks with the neoclassical analytical logic and in some cases returns to classical analysis- could converge towards a research programme along the lines suggested by Lakatos (1983). This would mean progressing towards a solid core consisting of i) an enterprise theory which assumes that the agents have limited rationality, imperfect information and suffer from uncertainty, and that they have to take their decisions in this context, and ii) a theory on technology and technical change which assigns a key role to the innovation process, understood as the process of transformation of generic knowledge into specific know-how and assimilation of both codified and tacit knowledge. The theory also makes new assertions that are as yet difficult to demonstrate empirically, especially the idea that experimental and tacit knowledge is decisive in developing the competitiveness of the agents. Within this theoretical framework, the interrelations between unproven and experimental knowledge (doxa) and proven knowledge (episteme) are excluded from most of the epistemology before and after Popper.
}

use in the generation of competitive advantages. The enterprise theory takes account in its arguments of the limited rationality of the agents, their imperfect access to information, and the non-modelable uncertainty of the environment they are operating in. Uncertainty -which is an essential element in the analysis- is a parameter that the agents cannot express in probabilistic terms: the incomplete information cannot be completed, and the agents take their decisions under this drawback. Consequently, the agents' potential for turning generic knowledge into specific know-how -the development of their innovative capacity (Lall, 1992; Boscherini and Yoguel, 1996a) - decisively affects the possibilities of generating competitive advantages and partially reducing the strategic uncertainties that exist in the markets they operate on. ${ }^{4}$ These theories start from the idea that a necessary condition for generating these learning processes is to have a certain minimum threshold level of capabilities (Rullani, forthcoming), which is lower in the case of the environments and countries where positive externalities are generated and the national innovation system works properly.

At the same time, as Dal Bó and Kosacoff (1998) point out, knowledge cannot be expressed entirely in explicit form, and hence cannot be transformed or converted into information as a tradeable good. This characteristic of knowledge introduced some highly specific aspects into the concept of technology, which must be considered not just as a stock of machines and production techniques, ${ }^{5}$ but basically as a complex system of generation and diffusion of codified and tacit knowledge (Bell and Pavitt, 1995) accumulated by firms (Ernst and Lundvall, 1997).

This conception of technology includes two aspects which are not covered in neoclassical analysis (Metcalfe,

\footnotetext{
${ }^{4}$ According to Poma (1998), the new international setting also includes less possibility of control over uncertainties by the agents. Thus, for example, in the framework of Fordism uncertainty could be controlled both on the supply side (through the creation of automatic and repetitive phases in mass production) and on the demand side (through the creation of new needs among consumers). In the case of industrial districts, the uncertainty that existed in market conditions was tackled through the certainty of shared values and the system of personal relations, while technological uncertainties were dealt with through incremental innovations. In the new setting, in contrast, uncertainty has increased because the complexity of competition has also increased.

${ }^{5}$ This level of analysis is associated with the neoclassical view, whereby technology is the set of capital goods and production processes embodied in the machinery or fully transferable through handbooks. From this point of view, technological change is the process by which economies change over time as regards the goods they produce and the processes used to produce them.
} 
1998). Firstly, it incorporates analysis of the capabilities of individuals and the capabilities generated within an organization, understood as the set of knowledge, routines, procedures, skills and practices available to it. These capabilities are more than just the total amount of technical and engineering knowledge, since they also include questions of organization and management connected with the functioning of the production process (David, 1985). According to this conception, technical progress is a succession of incremental innovations -much more significant than in the previous periodwhich complement radical innovations and indeed are more significant than them in some sectors. These improvements make it possible, using a given volume of resources, to produce more and better-quality goods, more efficiently. Secondly, the capacity to think and the implementation of applied learning processes also form part of technology. The literature on technological paths and paradigms (Pérez, 1985) considers that the starting point for the technical progress achieved by a firm is the equipment, the inputs, and the capabilities incorporated in individuals and organizations. These elements, together with the use of what Pérez (1983) calls "technical common sense", allow the agents to make either incremental innovations in the existing technology or radical changes in those branches where the ideal technological paradigm has not yet been reached.

Thus, firms do not select the best technology in the "library of technical knowledge" but, on the contrary, must make efforts of selection and adaptation which require certain minimum threshold levels of codified and, especially, tacit knowledge. While the codified component ${ }^{6}$ of the learning process is basically tradeable, the tacit component ${ }^{7}$ is firm-specific, cannot be bought on the market, and is a key factor in technological differ-

\footnotetext{
${ }^{6}$ Codified knowledge comprises the whole set of transmissible technological knowledge (embodied in materials, machines, components and final products) and organizational know-how (transmissible through such means of communication as the Internet, courses, etc.), which can be acquired through the market (Becattini and Rullani, 1993).

${ }^{7}$ Tacit knowledge comprises: i) know-how, not codified in handbooks, on applied technology as used in the work process; ii) general and conductual knowledge; iii) the capacity to solve non-codified problems, and iv) the capacity to link up situations and interact with other human resources. In short, tacit knowledge makes it possible to form a complex mental picture of the work process (Novick, 1998). These kinds of attributes which are demanded from workers (and which cannot be expressed specifically or completely formalized) are strongly influenced by the context (Mertens, 1996) and are acquired in various different ways such as on the shop floor or in associations or informal exchanges (Ducatel, 1998).
}

ences and in the specific competitive advantages of the agents (Lall, 1995). According to Poma (forthcoming), since tacit knowledge could be defined as the precipitation of the whole store of memories covering the sequences of operations that allow different objectives to be successfully attained, the use of a common (formal or informal) language is necessary in order for knowledge to be circulated and spread. In this sense, part of tacit knowledge must be placed within the framework of some formal parameters of thinking. Such a language can therefore be interpreted as an "institution" (whether formal or informal) that can facilitate or limit the learning process (Poma, forthcoming).

When access to codified knowledge is generally available to all the agents, such knowledge is not an element that leads to differences in forms of conduct and performance, but when not all the agents have access to codified knowledge because they have only imperfect information, they do not have the minimum capabilities needed, or they do not have the minimum tacit knowledge to assimilate it, then unequal access to codified knowledge can indeed become an element of differentiation.

According to Lall (1995), in order to create competitive advantages it is necessary not only to master the technology in a static sense -to reach the levels laid down in the handbooks- but also to carry out learning processes (with curves that cannot be predicted) which will enable firms to achieve better products and processes, to make changes in their organization, and to increase the complexity of the linkages with the local system. According to Ernst and Lundvall (1997), even to put codified knowledge into practice (interpretation of engineering and design handbooks, utilization of generic-type scientific and management knowledge, specification of quality criteria, etc.) an organization also needs tacit knowledge reflected in the organizational routines and collective experience of specific groups of the firm in the fields of research and development, management, production and marketing. Consequently, the development of tacit capabilities within the firm represents an intangible asset that is hard to transfer, can have a positive effect on the operating results, and can become a barrier to the entry into the market of agents who do not have this kind of knowledge. ${ }^{8}$

\footnotetext{
${ }^{8}$ As almost all the indicators of level of knowledge refer to formal education and research and development efforts, the image of the economics of learning is distorted and fails to reflect the importance of incremental innovation processes throughout the organization. In order to capture the degree of development of codified and tacit
} 
According to Nightingale (1996), as the development of knowledge -which forms part of the social fabric- depends on the innate capacity of individuals to recognize similarities, the tacit elements are of decisive importance. ${ }^{9}$ Learning does not mean simply accumulating more information, but recognizing different types of behaviour and connections between elements which are stored in the memory, and this depends on the knowledge accumulated through experience and the automatic capacity individuals have of linking up experience with knowledge.

In view of this, some authors suggest that the degree of mutual relation between codified and tacit knowledge decisively affects the efficiency that will be reached in a firm's learning process. These learning processes, which are generated in sectors with unequal degrees of technological development, involve not only formal training and research and development activities but also a set of informal activities which the agents do not always recognize as such (learning by doing, learning by interaction, learning by producing). These different types of learning processes are gradually accumulated during the active life of the agents and result in tangible and intangible assets of vital importance for competition. These assets are not eternal, however, because they must be weighed in the process of developing capabilities. While some are degraded and lose their value because they do not reach the minimum threshold levels demanded by the market, others are winners and gradually shape the elements in the predominant technological pattern.

In order to identify more precisely the different types of learning and their influence on the competitiveness of the agents, Johnson and Lundvall (1994) developed a typology in which four types of knowledge are distinguished, depending on their tacit or codified nature. The

\footnotetext{
knowledge which is not centered on specific research and development units, it is necessary to make use of other qualitative and quantitative indicators and embrace the idea that creative capacity is spread throughout the organization (Lassini, 1992). The progress made in this direction in Argentina is described in Boscherini and Yoguel (1996b), Boscherini, López and Yoguel (1997), Rearte, Lanari and Alegre (1997) and Moori-Koenig and Yoguel (1998).

${ }^{9}$ As Nightingale (1996) notes, tacit knowledge is of fundamental importance for understanding the meaning of the word "cut" in expressions such as i) cut a cake and ii) cut the grass. Although the same word is used in both cases, the meaning associated with "cut" is different in each context. The word "cut" thus has a different meaning which depends on the previously accumulated experimental knowledge (tacit knowledge), and this in turn differs between different individuals. In other words, the meaning of "cut" is linked with the prior tacit knowledge and is not immediately clear from the word on its own.
}

knowledge they call know-what may be assimilated to what would normally be classified as facts or information, while the knowledge they call know-why is of a scientific nature and refers to the principles and laws of movement of nature. Both are essentially codified knowledge and can be acquired on the market in the form of books, courses, data bases and similar sources. The types of knowledge they call know-how and know-who, in contrast, are of a tacit nature. The first of these refers to the skills acquired through direct experience in production and management activities. The second type is connected with the knowledge developed and maintained within an enterprise or research groups. Firms can gain access to this type of knowledge not only through their own activities but also through inter-firm cooperation and strategic alliances. In particular, access to know-who requires direct contact and communication between individuals and the development of relations of mutual confidence. In these circumstances, and as may be learnt in social practice, the agents with the greatest relative development (those of Silicon Valley, for example) establish links with formal and informal networks of scientists engaged in various fundamental research programmes potentially capable of practical application. This type of knowledge is therefore not usually transferred through formal information channels. ${ }^{10}$

As Ducatel (1998) suggests, the four forms of knowledge have strong mutual links. The development of codified knowledge (know-what and know-why) and the replication of experimental results depend on tacit knowledge and the recognition of the importance of know-who in the field of science and technology. Because of the limited rationality of the agents, in conditions of uncertainty (regarding future market conditions or the homogeneity of inputs, for example) a necessary condition for the development and incorporation of codified knowledge is often the existence of prior tacit elements which are not easy to codify. For its part, tacit knowledge -which has its origin in complexity and variations in quality, and which becomes particularly important in situations of uncertainty, where it is necessary to use different human capacities simultaneously and to relate different parameters with each other- likewise requires a certain minimum amount of prior codified knowledge. Although globalization and information technologies make access to codified options easier and cheaper through the Internet, they increase the strategic

\footnotetext{
10 This type of transfer of knowledge takes place through various forms of links between university research centres and enterprises.
} 
uncertainties of the agents and thus provide even stronger reasons to develop tacit knowledge.

The importance for the long-term success of the agents assumed by the tacit elements of knowledge in the new context, which is reflected in their capacity to adapt to change (flexibility) and to make changes themselves (innovation), is in sharp contrast with the lack of these elements in the production function characteristic of the traditional majority of firms. ${ }^{11}$

Thus, in an analytical framework of imperfect information and rationality, firms are faced with a situation of uncertainty which they cannot foresee and where technology is not just the purchase of machines accompanied by codified information. Cognitive factors and formal and informal learning processes take on vital importance for the development of innovation capability and hence for the competitiveness of the agents.

This growing role of cognitive processes in the construction of tangible and intangible assets is thus found not only within organizations - "intelligent organizations" (Bessant, 1991)- but also in the environments in which firms operate ("intelligent regions"). Within the organizations, the idea of qualifying firms is beginning to gain strength, and a transition is beginning to take place from the demand for qualifications typical of Fordist organizations to a demand for capabilities, which is a new trend that is still coexisting side by side with earlier forms. ${ }^{12}$

\section{III}

\section{The agents' technical and labour-related capabilities: tacit knowledge and}

\section{the development of competitive advantages}

In the development of technical knowledge within the enterprise and the possibility of the latter taking advantage of codified and tacit knowledge -within a context marked by limited rationality of the agents, imperfect information, uncertainty about the market situation and rapid technical change- the profile of the labour skills of the human resources involved is extremely important. These labour skills, understood as the total amount of knowledge of different origins and types possessed by the workers of an organization, have a number of characteristics which must be validated in the market and which exist in a state of uncertainty (Gallart, 1998). These characteristics refer to the capacity to solve problems, to learn and transmit knowledge to the organization on the basis of certain fundamental qualifications (Cariola and Quiroz, 1998), to manage resources and information, to

\footnotetext{
${ }^{11}$ The growing importance of the tacit aspects of the learning process has reduced the usefulness of the traditional methods of measuring learning, based largely on proxy variables of the formal aspects of learning of the organizations studied (research and development laboratories, patents, etc.). See in this respect, among others, Malerba (1993), Acs and Audrescht (1988), Lassini (1992), Malerba and Orsenigo (1993) and Boscherini and Yoguel (1996b).
}

develop interpersonal relations, to master technology (Mertens, 1996), ${ }^{13}$ and to analyse and select options out of a range of alternatives (Novick, Bartolomé, Buceta, Millavares and Senén González, 1998). Unlike the traditional qualifications of human resources, which could be validated with a training certificate, these broader capabilities can only be validated in specific working situations (Novick, Bartolomé, Buceta, Millavares and Senén González, 1998).

\footnotetext{
12 The neo-Schumpeterian authors commented upon in this section consider that in learning processes the economic agents combine codified "scientific" knowledge with another type of knowledge that can include both rational and non-rational elements with a strong inductive content. They therefore depart, from the epistemological point of view, from Popper's ideas: in the course of their learning process the agents evolve in the manner proposed by Lamarck (they can correct their paths) rather than through a Darwinian process of natural selection (Gómez, 1995).

${ }^{13}$ Information management is the capacity of human resources to seek, evaluate, process, interpret and communicate information; systemic comprehension is the capacity to understand complex interrelations and understand and design systems; mastery of technology takes the form of the ability to select and adapt technologies, and the development of interpersonal relations is the capacity to interact with human resources inside and outside the organization, to work as a team, to teach and to learn.
} 
As Mertens (1996) notes, workers are required to have a complex set of attributes, including in particular the capacity to assume more responsibility, to communicate, and to solve problems and learn, in addition to mental and manual skills. Within this set of qualities, the capacity to learn is the most important element, because of the greater complexity of innovation systems. Ducatel (1998) says that the capabilities required in the work process include i) the capacity to manage models in one's mind; ii) an understanding of the way machines work and interact; iii) the capacity to draw deductions from statistics; iv) oral and visual communication capability; v) willingness to accept individual responsibility for the work process and the product; vi) good judgement, and vii) skill in combining technical and business matters. In what this author calls the "learning triangle", the theoretical, vocational and experimental forms of knowledge interact, which demands a strong link between the work process and the educational system that is rarely found in practice. In so far as work is less and less capable of being directly observed but instead takes place largely in the worker's head (Hanser, 1995), labour skills involve new types of basic and technical, conductual and intellectual knowledge (Novick, Bartolomé, Buceta, Millavares and Senén González, 1998). ${ }^{14}$

In the process of developing capabilities, the agents can acquire tacit or general knowledge by using cooperation mechanisms that help it to circulate or creating a special form of organization of the work process which makes possible and stimulates the circulation, appropriation and generation of tacit knowledge. The capacity of firms to cope with the pressures of competition depends on the combination of codified and tacit knowledge that they develop within themselves. Thus, their potential to carry out this process depends on their initial capability and past performance, the degrees of freedom allowed by the technological patterns that apply, the local environment, their possible inclusion in networks in which these processes take place, and the way the work process and production are organized.

However, the process of learning by firms on the basis of codified and tacit knowledge can give either positive or negative results, starting off a process of "creative destruction" in which some firms generate solu-

\footnotetext{
${ }^{14}$ In Latin America, there are two tendencies which run counter to this. On the one hand, the fact that the production structure is increasingly based on primary-sector activities means that there is less demand for highly skilled human resources, while on the other the external flexibility of the labour market militates against the development of capabilities of the type referred to.
}

tions that enable them to stay in the market, other disappear, and still others enter the market for the first time. In a context where there are a variety of responses and degrees of freedom (Nelson, 1991) the selection of forms of conduct made by the market is imperfect, so that it is not always the best forms that survive. ${ }^{15}$

The generation and circulation of knowledge within a firm is a complex process whose intensity depends on: the need to solve concrete problems in a situation of uncertainty, which stimulates the demand for noncodifiable solutions; the degree of technical complexity of the equipment; the type of basic capabilities of the agents; the capacity to establish relations and work in a group, and the degree of utilization of the technical and organizational knowledge of the workers.

In particular, the generation and spread of tacit knowledge would appear to be associated with the characteristics of the human capital of the firm, the way the work process is organized, ${ }^{16}$ and the degree of importance that the interpretation and adaptation of external codified knowledge has for the firm. ${ }^{17}$ For the spread of tacit knowledge into the firm, the fundamental factor is the existence of networks and different types of linkages between the agents. The development of tacit knowledge within the firm is of a synergic nature, so that to a large extent the knowledge possessed by the individuals who form part of the organization is only of value within the firm and may have little value outside it. In other words, the stores of tacit knowledge possessed by individuals link together to form the competitive advantages of the organization and lose part of their value outside it.

Until tacit knowledge is disseminated and comes to be codified, the tacit elements possessed by firms form part of their capabilities and become an item of competitive advantage. For agent $h$ the competitive advantage depends on the possession of items of tacit knowledge $1,2 \ldots m$, and for agent $g$ his competitive advantage will depend on the items of tacit knowledge $n \ldots n+j$.

\footnotetext{
${ }^{15}$ These flaws in the selection of forms of conduct are a key element which is taken into account in policies aimed at creating mechanisms to minimize such flaws.

${ }^{16}$ Degree of flexibility, type of hierarchical organization, existence of cells, extent to which the wages of individual workers are linked with the performance of the group they belong to.

${ }^{17}$ This aims to assess the amount of additional development that the firm carries out on the goods and services that it purchases or obtains in codified form and the human resources that it hires, turning them into something which is different, special or specific and not appropriable by other agents (such as changes in the layout of plant, adaptation of "soft" technologies, or adaptation of information for the development of products or processes).
} 
For two agents $h$ and $j$, their competitive advantages may be expressed as follows:

$$
\begin{aligned}
& \text { Competitive advantage } h=F(t 1, t 2, t 3 \ldots t m) \\
& \text { Competitive advantage } j=G(t n \ldots t n+j)
\end{aligned}
$$

The competitive advantage of $h$ is greater than that of $j$ if the tacit elements $(1,2,3 \ldots m)$ possessed by agent $h$ delay longer in becoming codified than the elements $n, n+1$, $\ldots n+j$ possessed by agent $j$. In that case, we can say that agent $h$ will be able to appropriate his competitive advantages for a longer period of time. It may be noted that knowledge can be identified as a factor of production which has some special features that clearly take it out of the field of neoclassical analysis. On the one hand, the generation of knowledge (its production) increases with its consumption, thus clearly differentiating it from conventional factors of production. On the other hand, the synergies generated through the generation and dissemination of knowledge can mean that there are increasing returns to it, if there are virtuous linkages between public and private agents.

According to Ducatel (1998), the importance taken on by tacit knowledge shows up the shortcomings of the conventional educational system in terms of developing the capabilities of the agents. Formal education must be complemented with experience in order for the agents to acquire know-how. This consequently increases the importance of the interpersonal aspects of skills: the know-who side of the learning process. Mertens (1996) makes a detailed analysis of the elements that should be present in the formal educational system in order for it to be functional to the creation of the skills required in the production system. He considers that in the present-day world what is needed is not the senseless memorization of parallel subjects or the acquisition of relatively mechanical skills, but cross-ranging knowledge that can be updated in daily life and is reflected in the ability to solve problems different from those posed in the classroom. ${ }^{18}$ Skills are a multidimensional concept based on physical and cognitive capacity and interpersonal relations which, although they are generally not provided by the formal educational system, nevertheless require it as a precondition for their proper development. If we assume that the learning process is a social process, then in order to ensure competitiveness the relations developed both within the firm and between it and the rest of the agents are of decisive importance.

\section{IV}

\section{The practical manifestations of the learning process: local systems and enterprise networks}

It will be gathered from the foregoing that learning in an organization is something more than the application of conventional training processes. Nonaka and Takeuchi (1995) consider that a learning organization is one where inventing new knowledge is not a specialized activity, restricted to a small group, but a general form of behaviour extending to all the workers. What a learning organization needs is a broad variety of systems and procedures for capturing and mobilizing the know-how, know-who, know-what and know-why of its components in order to facilitate the various forms of conversion of knowledge. ${ }^{19}$

\footnotetext{
18 This is a major challenge for the educational system, which operates more as a body responsible for certifying qualifications than as a system for generating capabilities.

${ }^{19} \mathrm{~A}$ fundamental aspect of the work of these researchers is their definition of the dialectics of the four processes of conversion of knowl-
}

The aim of these systems is to involve the workers in learning practices and in the linking-up and application of knowledge. Achieving this requires the organization of team work, the existence of formal and informal training processes tailored to the needs of the firm and form-

\footnotetext{
edge and the forms of organization which make this possible: i) the conversion of tacit knowledge into another form of tacit knowledge: a phase known as the "socialization of knowledge"; ii) the conversion of tacit knowledge into codified knowledge, or the "externalization of knowledge" phase; iii) the phase of the combination of codified knowledge; and iv) the conversion of codified knowledge into tacit knowledge, called the "internalization of knowledge" phase. In addition to these four processes (socialization, externalization, combination and internalization) they propose a form of organization different both from "top downwards" systems based entirely on the predominance of codified knowledge and "bottom upwards" systems based solely on the importance assigned to tacit knowledge.
} 
ing part of a long-term approach, and the application of practical strategies designed to give the workers new skills so that they can carry out new tasks and take part in the planned rotation of jobs.

For Ducatel (1998), learning organizations display a certain set of characteristics. Thus: i) they have the ability to solve problems systematically; they usually start with a pre-established plan which they constantly review in order to consolidate their experience and use a type of management which expands the "critical mass" of ideas in the enterprise, encouraging the questioning of decisions, and which fosters the use of statistical techniques and the development of in-house thinking guided by considerations of intellectual rigour, discipline and precision; ii) they have the capability to experiment with new methods, to which end they promote systematic experimentation to test the new knowledge in operational programmes and projects and reward the taking of risks; this ensures that the lessons are effectively passed on to the entire organization and that its members learn to turn tacit knowledge (know-how) into codified knowledge that can be transferred both within the organization and to other agents; iii) they have the capability to learn from experience through the study of past errors and the systematic recording of results so that they can be made known to all the members of the organization, and iv) they have the capability to learn from others. In order to be able to do this, they are open to others, listen carefully, systematically analyse the results, carry out an ongoing analysis of the best practices, plan visits and interviews, get ideas from their clients on products, competitors and changes in preferences, observe their clients in action, and can transfer knowledge quickly and efficiently by preparing written, graphical and oral reports. This set of characteristics is to be observed in particular in the learning processes of agents who form part of local systems or enterprise networks.

\section{Interaction between the local and global levels: the role of the environment in the learning process}

Because of the systemic nature of competitiveness and the interactive character of innovation (Morgan, 1995), seen as a learning process in which new knowledge is introduced or existing knowledge is combined in order to generate new capabilities (Lundvall, 1992; Gregersen and Johnson, 1996), over the last twenty years the role of the local environment and its institutions in the development of the innovative capacity of enterprises has been taking on fresh significance. In the new international setting, the local environment and the global economy are not antagonistic terms, as globalization owes its force to the complexity of the knowledge and the synergy produced through the competitive confrontation of different territorial levels and networks of agents. ${ }^{20}$

From this standpoint, the local environment may be understood as the set of local institutions and agents and their mutual relations; its characteristics are of decisive importance for developing the creative capacity of enterprises. This environment may be seen as a public space which, in its positive aspects, can give rise to phenomena of collective efficiency, defined as the competitive advantages derived from external economies and the joint action of the agents (Camagni (ed.), 1991; Bianchi and Miller, 1994). ${ }^{21}$ The presence of a favourable environment can be reflected in the actions of the agents who make up civil society, who, thanks to their cooperation, capabilities and mutual pressures give rise to a collective tension which favours the development of innova-

${ }^{20}$ The interconnection of international financial markets associated with globalization helped to spark off these processes.

${ }^{21}$ Boscherini, Malet Quintar and Yoguel (1997) define a scale of theoretical local environments where the externalities differ as a function of the characteristics of the agents, the logic of the system, and the agents' strategies, as well as the degree of internal and external linkages of all the component elements. The environments in which the greatest positive externalities are generated are those which display the best characteristics in the three respects mentioned. In these environments there tend to be many agents (a large number of linkages, sectors and firms) with heterogeneous forms of production and little vertical integration, thus favouring inter-firm cooperation and the development of different forms of externalization. The degree of coverage of the (educational, information and services) institutions is high, and this is further heightened by their complementarity with each other. In this type of theoretical environment, a single type of logic may be identified, consisting of maintaining the core business, with business strategies tending towards the globalization, decentralization and in some cases vertical re-integration of the critical phases. The agents in these environments organize themselves without any visible coordination and form an advanced public space. The agents cooperate in production, trade and services activities and in problem-solving. The educational institutions carry out research and development work in conjunction with the firms, and the services they offer are in line with the agents' needs, within a strongly interactive framework. Finally, the relations with the world outside the local environment are based on links between groups of local institutions and enterprises and similar groups located outside the local system. At the other theoretical extreme, a negative type of environment generates the worst possible negative externalities for the firms. This type of environment is marked by the existence of only a small number of agents, with homogeneous forms of conduct and operating at a high level of vertical integration within an institutional system that fails to meet the minimum requirements for the development of individual and collective capabilities. No particular logic or strategy predominates in the functioning of the system. Without coordinating agents, the enterprises do not organize themselves as they did in the previous case. Finally, the agents do not have relations with the world outside the local system. 
tive strategies and minimizes the differences between agents. International experience suggests that when these environments behave in a positive manner they act like a quasi-market operator which reduces dynamic uncertainties, offsets weaknesses in the quality of organization, furthers learning processes, provides the agents with the capabilities they lack, aids in the process of dissemination of codified and tacit knowledge and tends to reduce social inequality (Camagni (ed.), 1991).

Thus, positive environments promote the generation of "social capital" constructed on the basis of complex links that are reflected in the development of mutual confidence among the agents (Morgan, 1995), which helps to reduce uncertainty and to spread codified and tacit knowledge. This type of environment is the result of individual and collective learning processes. Although a positive environment tends to make the forms of conduct of the agents more similar, its presence does not mean automatic benefits for all of them. Thus, in order to be able to take advantage of the externalities of the environment firms must have more than a certain minimum threshold level of capabilities and of endogenous generation and transmission mechanisms, without which the process of learning and transformation of knowledge will not take place. The generation of such capabilities in local environments is also the consequence of an evolutionary process of creation and destruction of routines and conventions (Gregersen and Johnson, 1996). Consequently, learning also requires the discarding of some things previously learned. In this process, firms modify the environment through the internal transformation of knowledge and the way they link up with other agents. The development of learning processes in local environments depends on the path followed by the agents in their evolution, the technological pattern of the sector they operate in, and the degree of development of the environment (Camagni (ed.), 1991).

In order to establish the real value of their specific features (knowledge, capabilities), the local and national spaces must be compared with similar spaces at the world level. Rullani (forthcoming) has clearly described the interaction between the codified and tacit aspects of the process of generating knowledge, with special emphasis on the role played by the environment. As the tacit elements have a strong contextual and experience-related component, in the globalized world of today the territorial dimension has a leading role in the generation of knowledge. The contextual, experimental and evolutionary nature of knowledge leads not only to the generation of tacit knowledge but also to its codification so that it can be transformed and possibly transferred. In this way, knowledge can circulate outside its original context and take on a non-territorial form, but in order to apply it effectively in another context it must be recontextualized.

From the territorial point of view, then, there are two poles in the cognitive circuit: i) the global dimension, which covers the process of production of knowledge and its transfer and use outside its context (codification) and ii) the local dimension, which includes the process of learning and precipitation, when the knowledge becomes rooted in the territorial area in question. Thus, according to Rullani (forthcoming), the generation of the economic agents' knowledge takes place in a local and specific context. For it to be taken out of that context and transferred, it must first be codified. In this stage, knowledge takes on a global and abstract character. For this abstract knowledge to be of use, however, it must be re-contextualized and subjected to a process of adaptation which makes possible the creation of tacit knowledge.

This process of codification and decodification of knowledge which links together the local and global levels is a product of what Becattini and Rullani (1993) call "versatile integration"; they note that the efficacy of the various forms of integration (technological, organizational and communicational) depends not only on the efficiency of the codes employed by the different agents but also, and especially, on the capabilities and skills acquired by direct experience which cannot be expressed in standardized codes. An aspect which takes on vital importance in the process of generation and circulation of tacit knowledge in local environments is the way the formal and informal modes of language link up among the agents (Poma, forthcoming). Whereas codified knowledge is always learnt in the same way, tacit knowledge goes through a process of interpretation by the person learning it and is therefore somewhat different from the knowledge of the agent who transferred it: this discrepancy between transmitting/circulating and learning adds something to the knowledge and introduces innovations in it and also in the language (ibid.).

\section{Learning processes in enterprise clusters}

The aspects dealt with earlier in connection with the process of generation and circulation of knowledge within a given environment are reproduced in enterprise clusters, with the special feature deriving from the predominance of horizontal and vertical input-output relations among the agents that form part of them. As a considerable number of transactions take place outside the mar- 
ket in these production networks or systems, tacit elements can take on even greater importance in them.

However, the intensity of the learning process in enterprise clusters will depend on the importance assigned to it both within the enterprise and by each of the agents that make it up, as well as on the degree of selforganization. The importance assumed by the tacit elements developed in the different sectors of production will depend on the depth of the exchange of experience and joint work, the importance of work in production cells, the circulation of information in each of the components of the production network, and the interaction with the local environment.

A very special feature of production networks is the synergy that can be generated in them by the learning process, which may be reflected in the generation of more numerous and more complex tacit elements, which become entry barriers to agents who do not already belong to the network. Thus, if agents $h$ and $j$, whose competitive advantages were described in the previous section, belong to network $\mathrm{Ti}$, the aggregate competitive advantage of the network will be greater than the sum of the functions of the agents that make it up, generating improvements in efficiency which may be assimilated to economies of scale and variety, taken together. Together with the joint development of tacit-type knowledge in enterprise clusters, however, there is also codification of tacit knowledge so that it can circulate through formal languages (Poma, forthcoming). ${ }^{22}$
The implementation of learning processes within enterprise clusters not only introduces changes in the training activities required but also in the way contracts are formulated and the implicit incentives. In the formal and informal relations that take place within a production network, the contracts and the fixing of prices involved in trading operations gradually acquire greater precision through the synergies generated in the joint learning process. While the minimum requirements of contracts (precision) would appear to be positively related to the level reached in the learning process, the rate of incentives would display an inverse relation with the level of learning: the greater the knowledge acquired, the fewer are the incentives needed to ensure that contracts work. The evolution of contracts assumes that the agents not only learn but also advance (there are changes in routines, new production processes are introduced, sunk investments are made, etc.); this process cannot be reversed and determines the initial positions in new contracts. In short, while the rate of risk is in inverse relation to the implementation of learning processes, the level of complexity of contracts is in direct relation to it. Consequently, as the rate of incentives needed for the formulation of contracts depends on the level of risk, the implementation of learning processes plays a decisive role -within the production network- in reducing the amount of incentives needed to make the system of contracts work. ${ }^{23}$

\section{V}

\section{Some final remarks}

As noted in the previous sections, in the new international setting the creation of competitive advantages by the agents depends on the implementation of learning processes of a systemic nature. These processes are affected not only by the set of individual characteristics of the agents, but also the degree of articulation of the local systems and the production networks of which they form part. From this point of view, the generation and circula-

\footnotetext{
22 According to Poma, this eliminates the discontinuities typical of the subjective interpretation of tacit knowledge and reduces the number of incremental innovations within it, giving rise to processes of more clearly-defined breaks which make possible the development of radical innovations.
}

tion of codified and tacit knowledge both within organizations and between them is powerfully influenced by: the complexity of the linkages that exist and the degree of formal and informal technological cooperation among the agents; the type of links between universities and research centres on the one hand and enterprises on the other; the training of human resources and the complexity of the educational and training system, and the de-

\footnotetext{
${ }^{23}$ Volkswagen's continuous improvement group is an interesting example of an informal technical assistance and training system designed to develop capabilities on the basis of the specific tacit knowledge of the participating agents, thus making possible its mobilization, codification and valuation by the agents of the production system
} 
gree of development of the intermediate agents (risk capital, specific technical services, professional associations, former students' groups, etc.) who also act as messengers (contacts) in the process of transmission and generation of information. As, in this new setting, knowledge is created and transferred in many different ways, informal areas of innovation grow up within enterprises and institutions which complement the activities of the research and development laboratories proper.

These processes are not the consequence of the natural, linear evolution of production systems, but require a long period of maturation. They should be interpreted as the result of a complex process of economic and social construction which takes time and has a historical form of evolution which is influenced by many different levels. In addition to formal and informal factors of a technological and economic nature, it is also influenced by other elements, especially the development of mutual confidence among the agents, the social valuation of the role of entrepreneur, and the degree of fulfillment of contracts. These are tendencies which, although still embryonic, are beginning to take root in the developed countries and also, with some delay, in the less developed nations.

in question. This generates new capabilities and knowledge which make it possible to resume the process of development of knowledge, starting from a higher level. In this process of technical assistance and training, the group operates as an intermediary (that is to say, as a technological adviser), which makes it possible to speed up the dissemination of knowledge. As it is based on the idea that he who really knows is the other party, this generates two-way integration of knowledge. In this sense, the training consists of directing knowledge of different types and levels, through a systematic process, to integrate higher-level technical knowledge with the knowledge possessed by those working directly in the production process. In the continuous improvement process, the training consists of generating a synergy of different types of knowledge to make possible external economies: thus, the synergy is greater than the knowledge contributed by each of the members of the system in question. The technological adviser programme applied in Argentina by the National Agency for the Promotion of Science and Technology of the Ministry of Science and Technology, which is aimed at small and medium-sized enterprises, is based on similar lines. The technological advisers assigned to groups of firms start from the level of the capabilities possessed by the agents and work together with them to develop their technological management capabilities. The idea is that, because of the flaws that exist in the technology market, what the enterprises want is not so much to obtain specific technical advice as to identify the key factors in developing the capabilities and innovative capacity of the firms (see Argentina, Presidencia de la Nación, Secretaría de Ciencia y Tecnología, 1997).
In order for the technological learning process to be successful in the developing countries, they need to acquire the necessary codified elements of the technology and develop the complementary tacit elements. In seeking to fulfill the first condition, they run up against flaws in the technology market, while in order to achieve the second they need first of all to build up capabilities in a prior evolution process which is often non-existent or incomplete. Consequently, the generation of competitive advantages linked with the intensive application of knowledge and more complex structures of production in the developing countries represents a challenge which goes beyond the actions of individual economic agents and calls for measures involving the public and private institutions and the other social agents as a whole.

Achieving these objectives requires, among other things: i) social revaluation of the processes of learning and education; ii) the creation of intermediary agents who will act as transmitters/translators between the different parts of the system and will spark off the learning processes of the agents and help to create the market; iii) the development of local environments that generate external economies; iv) the evolution from individual competitive advantages to competitive advantages based on enterprise clusters and local systems, and v) the establishment of effective links between the universities and the enterprises which boost the processes of codified and tacit learning.

The production specialization profile of most of the Latin American countries is biased towards the processing of natural resources or in-bond assembly activities and therefore hardly includes learning processes at all as a prime element for obtaining dynamic competitive advantages. In the future deepening of the development model (even if it continues to be based on the exploitation of natural resources), however, it will be necessary to pay greater attention to the issues mentioned above. Policy objectives such as strengthening added value chains, developing production capability for internationalization, integrating small and medium-sized enterprises in enterprise clusters and networks, and achieving a better territorial balance (Kosacoff (ed.), 1997) are directly linked to the development of the complex capabilities of the agents, which are difficult to obtain without a major learning process involving not only codified but also tacit knowledge.

(Original: Spanish) 


\section{Bibliography}

Acs, Z. and D. Audrescht (1988): Innovation in large and small firms: An empirical analysis, The American Economic Review, vol. 78, Nashville, Tennessee, American Economic Association, September.

Argentina, Presidencia de la Nación, Secretaría de Ciencia y Tecnología (1997): Plan Nacional Plurianual de Ciencia y Tecnología 1998-2000, Documento, $\mathrm{N}^{\circ}$ 1, Buenos Aires, Programa de Capacitación Tecnológica de Pymes Industriales.

Arrow, K. (1962): The economic implications of learning by doing, The Review of Economics Studies, vol. XXIX(3), $\mathrm{N}^{\circ}$ 80, London, London School of Economics.

Becattini, G. and E. Rullani (1993): Sistema locale e mercato globale, Economia e politica industriale, $\mathrm{N}^{\circ} 80$, Milan, Italy, Franco Angeli.

Bell, M. and K. Pavitt (1995): The development of technological capabilities, in I. ul Haque (ed.), Trade, Technology and International Competitiveness, Washington, D.C., World Bank, Economic Development Institute (EDI).

Bessant, J. (1991): Managing Advanced Manufacturing Technology, Manchester, U.K., NCC Blackwell.

Bianchi, P. and L. Miller (1994): Innovation, collective action and endogenous growth: An essay on institutions and structural change, in F. Boscherini and L. Poma (eds.), Territorio, conocimiento y competitividad en el espacio global, Buenos Aires, Universidad Nacional de General Sarmiento.

Boscherini, F., M. López and G. Yoguel (1997): Sistemas locales de innovación y el desarrollo de la capacidad innovativa de las firmas: un instrumento de captación aplicado al caso de Rafaela, Documento de trabajo, $\mathrm{N}^{\circ}$ 10, Buenos Aires, Economic Commission for Latin America and the Caribbean (ECLAC)/ Universidad Nacional de General Sarmiento, Instituto de Industrias.

Boscherini, F., N. Malet Quintar and G. Yoguel (1997): Consideraciones acerca del ambiente y el desarrollo de las capacidades innovativas de las firmas, Segundas Jornadas Nacionales de la Red Pymes, La Plata, Argentina, Centro de Estudios Bonaerense (CEB).

Boscherini, F. and G. Yoguel (1996a): La capacidad innovativa y el fortalecimiento de la competitividad de las firmas: el caso de las PYMEs exportadoras argentinas, Documento de trabajo, $\mathrm{N}^{\circ} 71$, Buenos Aires, ECLAC Office in Buenos Aires.

(1996b): Algunas consideraciones sobre la medición de los procesos innovativos: la relevancia de los rasgos informales e incrementales, Redes, Buenos Aires, Universidad Nacional de Quilmes, Centro de Estudios e Investigaciones.

Camagni, R. (ed.) (1991): Innovation Networks: Spatial Perspectives, London, Belhaven Press.

Cariola, M. and A. Quiroz (1998): Competencias generales, competencias laborales y curriculum, Montevideo, Inter-American Research and Documentation Centre on Vocational Training (CINTERFOR), International Labour Organisation (ILO).

Cimoli, M. and G. Dosi (1994a): De los paradigmas tecnológicos a los sistemas nacionales de producción e innovación, Comercio exterior, vol. 44, N 8, Mexico City, Banco Nacional de Comercio Exterior (BANCOMEXT).

(1994b): Technological Paradigms, Patterns of Learning and Development: An Introductory Roadmap, London.

Dal Bó, E. and B. Kosacoff (1998): Theoretical Approaches to the Microeconomic Evidence about Structural Change, Buenos Aires, ECLAC Office in Buenos Aires.

David, P.A. (1985): CLIO and the economics of QWERTY, The American Economic Review, vol. 75, $\mathrm{N}^{\circ} 2$, Nashville, Tennessee, American Economic Association.

Ducatel, K. (1998): Learning and Skills in the Knowledge Economy, Working Paper $\mathrm{N}^{\circ} 2$, Aalborg, Denmark, Danish Research Unit for Industrial Dynamics (DRUID).

ECLAC (Economic Commission for Latin America and the Caribbean) (1996): Quince años de desempeño económico. América Latina y el Caribe 1980-1995, Santiago, Chile.

Ernst, D. and A. Lundvall (1997): Information Technology in the Learning Economy: Challenges for Developing Countries, Working Paper $\mathrm{N}^{\circ} 12$, Aalborg, Denmark, Danish Research Unit for Industrial Dynamics (DRUID).

Gallart, S. (1998): Competitividad, redes productivas y competencias laborales, Montevideo, CINTERFOR, ILO.

Gómez, R. (1995): Neoliberalismo y seudociencia, Buenos Aires, Editorial Lugar.

Gregersen, B. and B. Johnson (1996): Learning economies, innovation systems and European integration, Regional Studies, vol. 31, Oxford, U.K., Pergamon Press .

Grossman, G. M. and E. Helpman (1992): Innovation and Growth in the Global Economy, Cambridge, Massachusetts, MIT Press.

Gutman, G. (1999): El sector agropecuario y el sistema agroalimentario: nuevos procesos, Buenos Aires, Instituto Torcuato di Tella, Centre for Urban and Regional Studies (CEUR).

Hanser, L. (1995): Traditional and Cognitive Job Analyses as Tools for Understanding the Skill Gap, Berkeley, California, University of California, National Center for Research in Vocational Education.

Johnson, B. and B.A. Lundvall (1994): Sistemas nacionales de innovación y aprendizaje institucional, Comercio exterior, vol. 44, $\mathrm{N}^{\circ}$ 8, Mexico City, BANCOMEXT.

Kosacoff, B. (ed.) (1997): Estrategia de desarrollo empresarial, Buenos Aires, ECLAC Office in Buenos Aires.

Lakatos, I. (1983): La metodología de los programas de investigación científica, Madrid, Alianza Editorial.

Lall, S. (1992): Technological capabilities and industrialization, World Development, vol. 20, N 2, Oxford, U.K., Pergamon Press.

(1995): The creation of comparative advantage: the role of industrial policy, in I. ul Haque (ed.), Trade, Technology and International Competitiveness, Washington, D.C., World Bank, EDI.

Lam, A.(1998): Tacit Knowledge, Organizational Learning and Innovation: A Societal Perspective, Working Paper $\mathrm{N}^{\circ} 22$, Aalborg, Denmark, Danish Research Unit for Industrial Dynamics (DRUID). 
Lassini, A. (1992): Il ruolo dell'attività di R\&S per lo sviluppo della competitività delle PMI, in F. Onida, G. Viesti and A.M. Falzoni (eds.), I distretti industriali: crisi o evoluzione?, Milan, Italy, Egea.

Lundvall, B.A. (1992): The learning economy: Challenges to economic theory and policy, paper presented at the EAEPE Conference, Copenhagen, Denmark, European Association for Evolutionary Political Economy (EAEPE).

Malerba, F. (1993): National systems of innovation: The case of Italy, in R. Nelson (ed.), National Innovation Systems, Oxford, U.K., Oxford University Press.

Malerba, F. and L. Orsenigo (1993): L'accumulazione delle capacità tecnologiche nell'industria italiana (1969-1984), in L. Filippini (ed.), Innovazione tecnologica e servizi alle imprese, Milan, Italy, Franco Angeli.

Mertens, L. (1996): Competencia laboral: sistemas, surgimiento y modelos, Montevideo, CINTERFOR, ILO.

Metcalfe, S. (1998): Evolutionary Economics and Creative Destruction, London, Routledge.

Moori-Koenig, V. and G. Yoguel (1998): Capacidades innovadoras en un medio de escaso desarrollo del sistema local de innovación, Comercio exterior, vol. $48, \mathrm{~N}^{\circ} 8$, Mexico City, BANCOMEXT.

Morgan, K. (1995): The Learning Region: Institutions, Innovation and Regional Renewal, Cardiff, University of Wales.

Nelson, R. (1991): Why Do Firms Differ and How Does it Matter?, Working Paper $\mathrm{N}^{\circ}$ 7, Berkeley, California, University of California, Center for Research Management.

Nightingale, P. (1996): A Cognitive Model of Innovation Electronics, Working Paper $\mathrm{N}^{\circ} 11$, Sussex, Science Policy Research Unit (SPRU).

Nonaka, I. and H. Takeuchi (1995): The Knowledge-Creating Company: How Japanese Companies Create the Dynamics of Innovation, London, Oxford University Press.

Novick, M. (1998): Estrategias y capacitación y aprendizaje de las firmas. Reflexión sobre empresas innovadoras en Argentina, Brasil y México, paper presented to the ECLAC/ GTZ Joint Project on Policies to Improve the Quality, Ef- ficiency and Relevance of Vocational Training in Latin America and the Caribbean, Santiago, Chile, EClAC.

Novick, M., M. Bartolomé, M. Buceta, M. Miravalles and C. Senén González (1998): Nuevos puestos de trabajo y competencias laborales, Papeles de la Oficina Técnica, $\mathrm{N}^{\circ}$ 6, Montevideo, CINTERFOR, ILO.

Novick, M. and L. Gallart (1998): Competitividad, redes productivas y competencias laborales, Geneva, ILO.

Pérez, C. (1983): Structural change and the assimilation of the new technology in the economic and social system, Futures, vol. 15, $\mathrm{N}^{\circ}$ 5, Surrey, U.K., IPC Science and Technology Press.

(1985): Microelectronics, long waves and world structural change: New perspectives for developing countries, World Development, vol. 13, $\mathrm{N}^{\circ}$ 3, Oxford, U.K., Pergamon Press.

Poma, L. (1998): La nuova competizione territoriale, Politica e organizzazione, Quaderni adoc, $\mathrm{N}^{\circ} 1$, Bologna, Italy, Il Mulino

(forthcoming): La producción de conocimiento. Nuevas dinámicas competitivas para el territorio, conocimiento y competitividad en el espacio global, in F. Boscherini and L. Poma (eds.), Territorio, conocimiento y competitividad en el espacio global, Buenos Aires, Universidad Nacional de General Sarmiento.

Rearte, A., E. Lanari and P. Alegre (1997): Sistemas de innovación y el desarrollo de la capacidad innovativa de las firmas: el caso de Mar del Plata, Buenos Aires, Universidad Nacional de Mar del Plata.

Rullani, E: (forthcoming): El valor del conocimiento, in F. Boscherini and L. Poma (eds.), Territorio, conocimiento y competitividad en el espacio global, Buenos Aires, Universidad Nacional de General Sarmiento.

Samuelson, P. (1962): Parable and realism in capital theory: The surrogate production function, Review of Economics Studies, vol. XXIX(3), ํㅛ 80, London, London School of Economics.

Solow, R. (1963): Capital Theory and the Rate of Return, Amsterdam, The Netherlands, North-Holland Publishing Company. 